\title{
A Profile of Putative Parasitism Genes Expressed in the Esophageal Gland Cells of the Root-knot Nematode Meloidogyne incognita
}

\author{
Guozhong Huang, ${ }^{1}$ Bingli Gao, ${ }^{1}$ Tom Maier, ${ }^{2}$ R. Allen, ${ }^{1}$ Eric L. Davis, ${ }^{3}$ Thomas J. Baum, ${ }^{2}$ and \\ Richard S. Hussey ${ }^{1}$ \\ ${ }^{1}$ Department of Plant Pathology, University of Georgia, Athens 30602-7274, U.S.A.; ${ }^{2}$ Department of Plant Pathology, lowa \\ State University, 351 Bessey Hall, Ames 50011, U.S.A.; ${ }^{3}$ Department of Plant Pathology, North Carolina State University, \\ Box 7616, Raleigh 27695-7616, U.S.A.
}

Submitted 1 November 2002. Accepted 12 January 2003.

Identifying parasitism genes encoding proteins secreted from a nematode's esophageal gland cells and injected through its stylet into plant tissue is the key to understanding the molecular basis of nematode parasitism of plants. Meloidogyne incognita parasitism genes were cloned by microaspirating the cytoplasm from the esophageal gland cells of different parasitic stages to provide mRNA to create a gland cell-specific cDNA library by long-distance reversetranscriptase polymerase chain reaction. Of 2,452 cDNA clones sequenced, deduced protein sequences of $185 \mathrm{cDNAs}$ had a signal peptide for secretion and, thus, could have a role in root-knot nematode parasitism of plants. Highthroughput in situ hybridization with cDNA clones encoding signal peptides resulted in probes of 37 unique clones specifically hybridizing to transcripts accumulating within the subventral (13 clones) or dorsal ( 24 clones) esophageal gland cells of $M$. incognita. In BLASTP analyses, $73 \%$ of the predicted proteins were novel proteins. Those with similarities to known proteins included a pectate lyase, acid phosphatase, and hypothetical proteins from other organisms. Our cell-specific analysis of genes encoding secretory proteins provided, for the first time, a profile of putative parasitism genes expressed in the $M$. incognita esophageal gland cells throughout the parasitic cycle.

Additional keywords: gland-cell cDNA library, plant-parasitic nematode, stylet secretions.

Root-knot nematodes, Meloidogyne spp., synthesize secretory proteins in their dorsal and subventral esophageal gland cells and release these proteins through a hollow, protrusible stylet (feeding structure) during migration within plant roots and subsequent modification of root cells into the elaborate permanent feeding cells, called giant-cells (Hussey and Grundler 1998). In preparasitic second-stage juveniles, the most active esophageal glands are the two subventral gland cells, while the single dorsal gland cell becomes the predominate source of secretions released through the stylet in subsequent parasitic stages, indicating that gland function and their

Corresponding author: R. S. Hussey; Telephone: +1-706-542-1254; Fax: +1-706-542-1262; E-mail: hussey@arches.uga.edu

Nucleotide and/or amino acid sequence data have been submitted to the DDBJ/EMBL/GenBank databases. secreted proteins change during the parasitic cycle (Davis et al. 2000, Hussey 1989). With very few exceptions, the identities of these secretory proteins are completely unknown and the mechanism of Meloidogyne parasitism of plants remains obscure. The cloning and identification of parasitism genes encoding esophageal gland proteins secreted from the nematode stylet into host tissue is now increasing our understanding of the molecular mechanisms of nematode parasitism of plants.

The first nematode parasitism genes expressed in the esophageal gland cells to be cloned encoded $\beta$-1,4-endoglucanases (cellulases) and were identified in cyst nematodes, Heterodera and Globodera spp. (Smant et al. 1998; Yan et al. 1998). Soon thereafter, cellulase parasitism genes also were identified in root-knot nematodes (Rosso et al. 1999). Cellulases are developmentally expressed in the subventral gland cells of cyst and root-knot nematodes and are secreted within host root tissue by infective second-stage juveniles during the migration phase of the infection process, which confirmed the in planta secretion of a parasitism gene product (Wang et al. 1999).

Differential gene expression, cDNA library screening, and direct analysis of secreted proteins have been used to clone parasitism genes expressed in Meloidogyne spp. esophageal gland cells, but with only limited success (Ding et al. 1998; Doyle and Lambert 2002; Jaubert et al. 2002; Lambert et al. 1999; Rosso et al. 1999). Whole nematode expressed sequence tag (EST) analysis also has been used to identify gland expressed genes. However, this approach has limited potential because it predominately identifies only genes whose translation products are obviously related to parasitism, like cell-wall digesting enzymes (Dautova et al. 2001). Recently a novel method for directly cloning expressed nematode parasitism genes was developed by microaspirating the cytoplasm from the esophageal gland cells of parasitic nematode stages to provide mRNA to construct gland cell-specific cDNA libraries by reverse-transcriptase polymerase chain reaction (RT-PCR) (Gao et al. 2001; Wang et al. 2001). Suppression subtractive hybridization (Gao et al. 2001) and signal peptide selection (Wang et al. 2001) of gland-cell cDNA libraries from Heterodera glycines were conducted to enrich for expressed parasitism gene products and resulted in the cloning of several putative parasitism genes expressed in the subventral and dorsal esophageal gland cells. Coupling large-scale EST analysis of a gland-cell cDNA library, identification of cDNAs encoding an $\mathrm{N}$-terminal signal peptide sequence for secretion, and highthroughput in situ mRNA hybridization in nematode developmental stages has provided here a suite of 37 candidate parasit- 
ism genes expressed in the esophageal gland cells of Meloidogyne incognita during the parasitic cycle.

\section{RESULTS}

Analysis of the $M$. incognita gland-cell library.

A gland-cell cDNA library was constructed by long-distance (LD)-PCR (SMART System) using mRNA from the cytoplasm microaspirated directly from the esophageal gland cells of 43 different $M$. incognita specimens representing all parasitic life stages. Gel analysis of 20 clones randomly selected from the gland-cell LD-PCR cDNA library showed that insert sizes ranged from $350 \mathrm{bp}$ to $3 \mathrm{~kb}$. A cDNA library prepared similarly from intestinal cells of $M$. incognita hybridized to a macroarray of 6,144 clones of the $M$. incognita gland-cell cDNA library identified common housekeeping and structural genes and enabled the efficient isolation of candidate parasitism genes among the nonhybridized glandcell cDNA clones. High-quality sequences from the nonhybridized gland-cell cDNA clones were obtained for 2,452 sequences which produced 307 contigs representing 1,239 sequences. SignalP analyses predicted protein sequences of 185
cDNAs from 2,452 cDNA sequences to contain N-terminal signal peptides for secretion. The presence of a signal peptide prioritized these esophageal gland cell proteins as candidates for being secreted by $M$. incognita and potentially having a biological function in the nematode-host interaction. High-throughput in situ mRNA hybridizations were conducted on the 185 clones to confirm expression within the esophageal gland cells of $M$. incognita specimens. Probes of 37 distinct cDNA clones specifically hybridized to transcripts accumulating within the subventral (13 clones) or dorsal (24 clones) esophageal gland cells of $M$. incognita (Table 1; Fig. 1). By fulfilling the two criteria of gland expression and encoding proteins with signal peptides, these clones can be regarded as candidate parasitism genes. Probes of a few clones hybridized to mRNA in tissues adjacent to the esophageal gland cells (e.g. nerve ring, metacorpus, and esophago-intestinal cells) while the remainder of the probes did not hybridize within specimens of $M$. incognita. Fulllength cDNAs sequences with predicted open reading frames for these candidate parasitism genes ranged in size from 362 bp to $2.2 \mathrm{~kb}$ (Table 1). The predicted open reading frames were determined by the presence of i) translation initiation

Table 1. Summary of 37 distinct putative parasitism genes encoding proteins preceded by a signal peptide for secretion and expressed exclusively within the esophageal gland cells of Meloidogyne incognita

\begin{tabular}{|c|c|c|c|c|c|c|c|}
\hline \multirow[b]{2}{*}{ Clone } & \multirow[b]{2}{*}{ Accession no. ${ }^{\text {b }}$} & \multirow[b]{2}{*}{ FL/ORF (bp) ${ }^{c}$} & \multirow[b]{2}{*}{ Highest homology } & \multirow[b]{2}{*}{ Blastp score/E value } & \multicolumn{3}{|c|}{ Gland expression $^{a}$} \\
\hline & & & & & Pre-J2 & Par-J2 & J3-A \\
\hline 2E07 & AF531160 & $694 / 522$ & Pioneer $^{\mathrm{d}}$ & & $\ldots$ & DG & DG \\
\hline $2 \mathrm{G} 02$ & AF531161 & $776 / 630$ & Pioneer & & $\ldots$ & SvG & \\
\hline $2 \mathrm{G} 10$ & AY135363 & $999 / 384$ & Pioneer & & $\ldots$ & DG & DG \\
\hline 4D01 & AF531162 & $785 / 522$ & Hypothetical protein-Caenorhabditis elegans & $51 / 7 \mathrm{e}^{-06}$ & $\ldots$ & SvG & $\ldots$ \\
\hline $4 \mathrm{D} 03$ & AY135364 & $864 / 573$ & Hypothetical protein-C. elegans & $132 / 2 \mathrm{e}^{-30}$ & $\ldots$ & DG & DG \\
\hline $5 \mathrm{G} 05$ & AY135362 & $977 / 813$ & Hypothetical protein-C. elegans & $165 / 5 \mathrm{e}^{-40}$ & $\ldots$ & $\mathrm{SvG}$ & \\
\hline $6 \mathrm{~F} 06$ & AF531163 & $1339 / 990$ & Hypothetical protein-Methanosarcina mazei & $54 / 2 \mathrm{e}^{-06}$ & $\ldots$ & DG & DG \\
\hline 6G07 & AF531164 & $762 / 291$ & Pioneer & & $\ldots$ & DG & DG \\
\hline 7A01 & AF531165 & $778 / 540$ & Pioneer & & $\ldots$ & DG & DG \\
\hline 7E12 & AF531166 & $757 / 528$ & Pioneer & & $\ldots$ & DG & DG \\
\hline $7 \mathrm{H} 08$ & AF531168 & $1091 / 900$ & Pioneer & & $\ldots$ & DG & DG \\
\hline 8D05 & AF531169 & $1282 / 990$ & Pioneer & & SvG & SvG & $\mathrm{SvG}$ \\
\hline $8 \mathrm{H} 11$ & AF531170 & $1228 / 954$ & Hypothetical protein-C. elegans & $62 / 1 \mathrm{e}^{-08}$ & SvG & $\mathrm{SvG}$ & $\mathrm{SvG}$ \\
\hline 9H10 & AF531167 & $737 / 534$ & Pioneer & & $\ldots$ & DG & DG \\
\hline $10 \mathrm{~A} 08$ & AY142117 & $656 / 498$ & $\begin{array}{l}\text { Sodium/calcium/potassium exchanger-Tursiops } \\
\text { truncatus }\left(99 \% \text { identity to } 5^{\prime} \text { end of } 8 \mathrm{H} 11 \text { ) }\right.\end{array}$ & $58 / 4 \mathrm{e}^{-08}$ & SvG & SvG & $\mathrm{SvG}$ \\
\hline 10G02 & AY135365 & $1499 / 1242$ & Hypothetical protein-Leishmania major & $54 / 5 \mathrm{e}^{-06}$ & $\ldots$ & DG & DG \\
\hline $11 \mathrm{~A} 01$ & AY134431 & $1266 / 447$ & Pioneer $(89 \% \text { identity to } 2 \mathrm{E} 07)^{\mathrm{e}}$ & & $\ldots$ & DG & DG \\
\hline $12 \mathrm{H} 03$ & AY134432 & $723 / 552$ & Pioneer (97\% identity to $7 \mathrm{~A} 01$ ) & & $\ldots$ & DG & DG \\
\hline $13 \mathrm{~A} 12$ & AY134433 & $824 / 522$ & Pioneer ( $90 \%$ identity to $2 \mathrm{E} 07$ ) & & $\ldots$ & DG & DG \\
\hline 14E06 & AY134434 & $696 / 525$ & Pioneer (98\% identity to 7E12) & & $\ldots$ & DG & DG \\
\hline $16 \mathrm{D} 10$ & AY134435 & $364 / 129$ & Pioneer & & $\ldots$ & SvG & $\mathrm{SvG}$ \\
\hline $16 \mathrm{E} 05$ & AY134436 & $1687 / 1311$ & Pioneer & & $\ldots$ & DG & \\
\hline $17 \mathrm{H} 02$ & AY134437 & $783 / 516$ & Pioneer & & $\ldots$ & DG & DG \\
\hline 19F07 & AY142116 & 798/645 & Pioneer & & $\ldots$ & DG & DG \\
\hline $21 \mathrm{E} 02$ & AY134438 & $704 / 528$ & Pioneer (95\% identity to 7E12) & & $\cdots$ & DG & DG \\
\hline $25 \mathrm{~B} 10$ & AY142118 & $414 * / 333$ & Pioneer & & $\ldots$ & DG & $\ldots$ \\
\hline 28B04 & AY142119 & $748 / 519$ & Pioneer (95\% identity to 7E12) & & $\ldots$ & DG & DG \\
\hline $30 \mathrm{G} 11$ & AY 134440 & $1511 / 1374$ & Acid phosphatase-C. elegans & $214 / 2 \mathrm{e}^{-54}$ & SvG & SvG & $\ldots$ \\
\hline $30 \mathrm{H} 07$ & AY134439 & $994 / 783$ & Pioneer & & SvG & SvG & $\ldots$ \\
\hline $31 \mathrm{H} 06$ & AY134441 & $362 / 150$ & Pioneer & & SvG & SvG & $\ldots$ \\
\hline $34 \mathrm{C} 04$ & AF527788 & $1124 / 813$ & Pectate lyase $-M$. javanica & $477 / 1 \mathrm{e}^{-134}$ & SvG & SvG & $\ldots$ \\
\hline 34D01 & AY134442 & $782 / 540$ & Pioneer ( $89 \%$ identity to $7 \mathrm{~A} 01$ ) & & $\ldots$ & DG & DG \\
\hline $34 \mathrm{~F} 06$ & AY134443 & $801 / 357$ & Pioneer & & $\ldots$ & DG & DG \\
\hline $35 \mathrm{~A} 02$ & AY134444 & $2210 / 1848$ & Pioneer & & SvG & SvG & SvG \\
\hline 35E04 & AY142121 & $836 / 441$ & Pioneer ( $99 \%$ identity to $5^{\prime}$ end of $19 \mathrm{~F} 07$ ) & & $\ldots$ & DG & DG \\
\hline $35 \mathrm{~F} 03$ & AY142120 & $398 / 141$ & Pioneer & & $\ldots$ & DG & $\ldots$ \\
\hline $42 \mathrm{G} 06$ & AF049139 & $860 / 609$ & Cellulose binding protein $-M$. incognita & $352 / 1 \mathrm{e}^{-96}$ & SvG & $\ldots$ & $\ldots$ \\
\hline
\end{tabular}

${ }^{\mathrm{a}}$ In situ hybridization of cDNA probes to mRNA specifically within the $M$. incognita dorsal esophageal gland cell (DG) or subventral esophageal gland cells (SvG) in preparasitic second-stage juveniles (Pre-J2), parasitic J2 (Par-J2), or later stages (J3-A). .. = Not detected.

${ }^{\mathrm{b}}$ New sequences submitted to GenBank with the exception of AF049139, which was already in the database.

${ }^{\mathrm{c}}$ Size of the full-length clone with predicted open reading frame (ORF) size; * indicates not full length.

${ }^{\mathrm{d}}$ Novel transcript with no homology to any genes in the public databases.

${ }^{\mathrm{e}}$ Percent identity in the amino acid residues of predicted protein. 
and termination signals, ii) a polyadenylation signal sequence, and iii) a putative signal peptide at the $\mathrm{N}$-terminal end of the predicted protein. Most interesting, PSI-BLASTP analyses revealed $73 \%$ of the putative parasitism genes to encode novel protein sequences specific to $M$. incognita ( $E$ value $<0.005)$.

The predicted proteins of several putative parasitism gene contig members differed slightly in their amino acid identity and therefore, represented gene families (Table 1). For example, predicted proteins of clones 2E07, 11A01, and 13A12 shared 89 to $98 \%$ sequence identity. Interestingly, predicted proteins of the dorsal gland-expressed clones 19F07 (228 amino acids) and 35E04 (147 amino acids) had identical sequences for the first 146 amino acids from the 5' end. Similarly, sequences of proteins encoded by the subventral glandexpressed clones 8H11 (318 amino acids) and 10A08 (166 amino acids) were $99 \%$ identical for the first 165 amino acids from the $5^{\prime}$ end.

Only four candidate $M$. incognita parasitism genes had homologues with known functions in other organisms. The predicted amino acid sequence of the full-length cDNA of 34C04 had significant similarity to pectate lyases found in plant-parasitic nematodes and fungi. Clone 30G11 encoded an acid phosphatase with homologues in the free-living nematode, Caenorhabditis elegans, and other organisms. The predicted protein of clone 10A08 was similar to sodium/calcium/potassium exchanger from other organisms. Clone $42 \mathrm{G} 06$ encoded a cellulose-binding protein with a novel N-terminal domain, which was previously cloned from M. incognita (Ding et al. 1998).
Four other predicted proteins encoded by the putative parasitism genes were similar to hypothetical proteins of $C$. elegans. Although $64 \%$ of all 2,452 gland cDNA predicted protein sequences had homologues $(E$ value $<0.05)$ in $C$. elegans, only $19 \%$ of the products of the putative parasitism genes were homologous with $C$. elegans proteins. Only one of the $M$. incognita putative parasitism gene cDNAs (clone 34C04) was transspliced with the Meloidogyne 22 nucleotide leader sequence (SL1M) or derivatives thereof (Blumenthal and Steward 1997; Ray et al. 1994).

One of the predicted proteins $(7 \mathrm{H} 08)$ of the putative parasitism genes contained a canonical nuclear localization signal (SV40-like seven-residue pattern class) and was predicted by PSORT II analyses to be targeted to the nucleus. mRNA of this novel predicted nuclear protein was detected exclusively within the dorsal gland cell (Table 1). Domain analysis using the SMART database revealed the predicted proteins of six cDNA clones (5G05, 6F06, 8D05, 8H11, 10A08, and 30H07) contained coiled-coil domains and three clones $(7 \mathrm{H} 08,8 \mathrm{H} 11$, and 35A02) had internal repeats.

\section{Developmental expression.}

Variations in developmental regulation as well as the level of expression of the putative parasitism genes in the esophageal gland cells of $M$. incognita were detected by the in situ mRNA hybridizations (Fig. 1; Table 1). Observable mRNA abundance of specific parasitism genes in the gland cells ranged from low (Fig. 1A) to high (Fig. 1F and I) based on the relative intensity of the hybridization signal. Developmental expression patterns
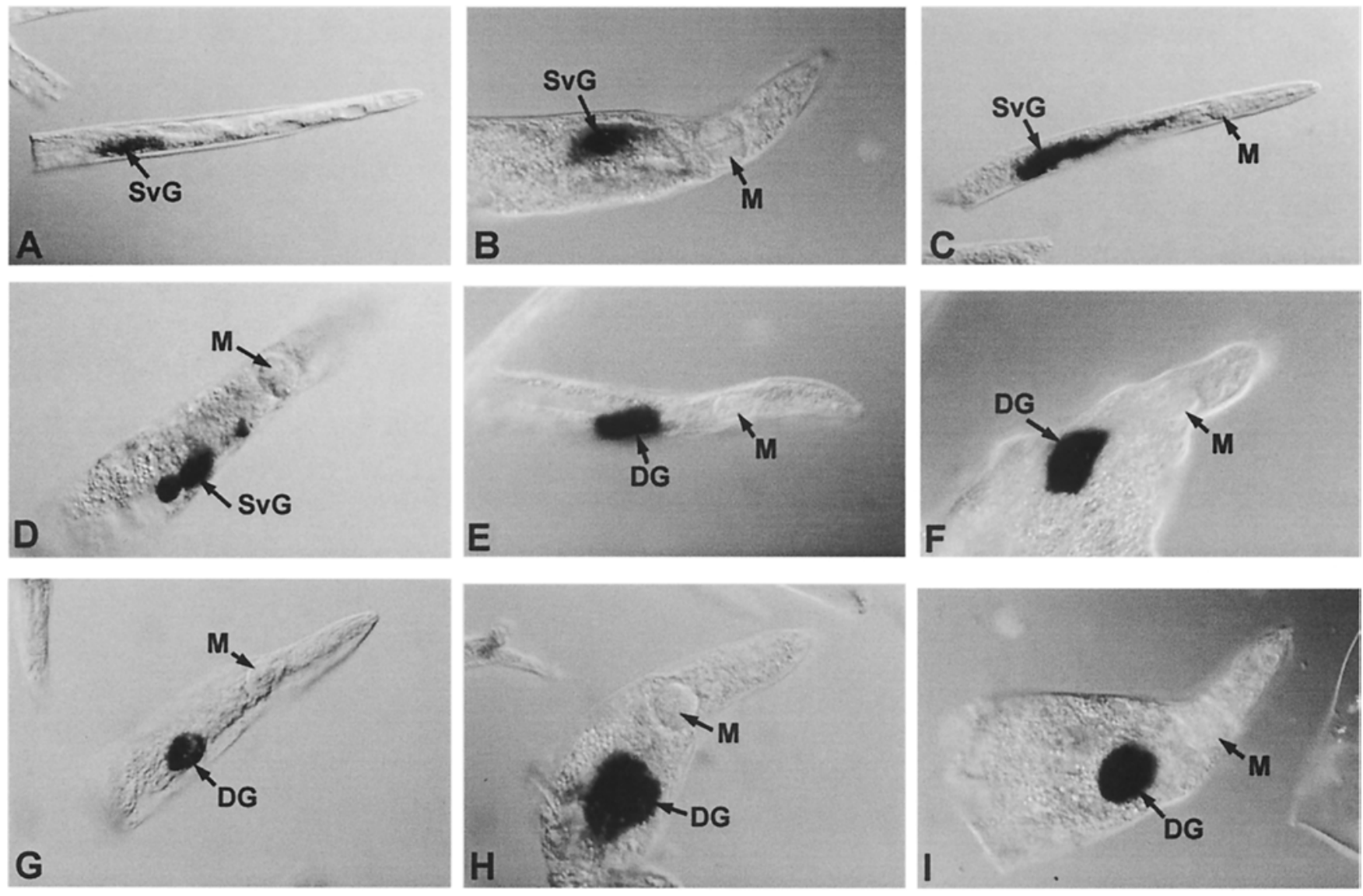

Fig. 1. Hybridization of digoxigenin-labeled antisense cDNA probes (dark staining) of parasitism gene clones to transcripts expressed exclusively within the subventral or dorsal esophageal gland cells of Meloidogyne incognita at different life stages. Clone 8D05: A, Preparasitic second-stage juvenile and B, late parasitic second-stage juvenile; clone 16D10: C, migratory parasitic second-stage juvenile and D, late parasitic second-stage juvenile; clone 11A01: $\mathbf{E}$, early parasitic second-stage juvenile and $\mathbf{F}$, young adult female; clone $9 \mathrm{H} 10$ : $\mathbf{G}$, parasitic second-stage juvenile and $\mathbf{H}$, late parasitic second-stage juvenile; clone 7A01: I, young adult female. $\mathrm{DG}=$ dorsal gland cell, $\mathrm{M}=$ metacorpus, $\mathrm{SvG}=$ subventral gland cells. 
of the parasitism genes also varied greatly throughout the $M$. incognita life cycle (Fig. 1; Table 1). Although mRNA of most parasitism genes expressed in the subventral gland cells usually was detectable only in the nonfeeding preparasitic and migratory parasitic second-stage juveniles (Fig. 1A and C), transcripts of a few subventral gland cell-expressed parasitism genes also were detected in feeding sedentary second-stage juveniles and later parasitic stages (Fig. 1B and D). On the other hand, parasitism gene expression in the dorsal gland cell usually was restricted to the feeding sedentary parasitic stages (Fig. 1E, F, G, H, and I).

\section{DISCUSSION}

Products of parasitism genes expressed in nematodes' esophageal gland cells and secreted through their stylet (feeding spear) are thought to control the process of plant parasitism (Williamson and Hussey 1996). The production of esophageal gland proteins is developmentally regulated during a root-knot nematode's life cycle (Davis et al. 1994); therefore, obtaining a comprehensive profile of the parasitism genes requires analyzing gene expression in the esophageal gland cells throughout the parasitic cycle. By combining EST analysis of a gland-cell LD-RT-PCR cDNA library with high-throughput in situ screening of the clones encoding a signal peptide for secretion, we obtained a profile of $37 \mathrm{cDNA}$ sequences encoding putative parasitism genes expressed exclusively within the secretory esophageal gland cells of $M$. incognita throughout the parasitic cycle.

The most surprising and interesting result of our study was the large number of the putative parasitism genes encoding novel proteins. Indeed, 27 sequences had no homology with functionally annotated genes in the databases (homologues of six other clones were hypothetical proteins). These "pioneer" genes will provide a significant challenge to determine their roles in Meloidogyne spp. parasitism of plants. Nevertheless, these pioneering sequences are intriguing candidates for functional assays. For example, clone 16D10, which was expressed in the subventral gland cells, encodes a 13 amino acid secretory peptide that possibly may function as a peptide signal secreted by $M$. incognita during the parasitic process. Small peptides represent a new class of signaling molecules now being identified in plants with functions in cell division control, defense responses, and reproductive mechanism (Lindsey et al. 2002). Recently, it was observed that a low molecular weight peptide or peptides secreted by Globodera rostochiensis enhanced plant cell proliferation (Goverse et al. 1999). The coiledcoil domains in predicted proteins of six candidate parasitism genes suggests a possible function in a structural protein (e.g., in formation of the $M$. incognita feeding tube wall) (Hussey and Mims 1991), or in binding to host molecules, because coiled-coil domains in proteins fulfill a variety of functions (Lupas 1996).

The pectate lyase encoded by clone 34C04 was the second category, after cellulases, of cell wall-degrading enzymes found to be encoded by parasitism genes. Like the cellulases, the pectate lyases are expressed in the subventral esophageal gland cells of plant-parasitic nematodes with a presumed function in nematode migration in plant roots (Davis et al. 2000; de Boer et al. 2002; Doyle and Lambert 2002; Popeijus et al. 2000). Furthermore, clone 34C04 was the only candidate parasitism gene trans-spliced with a leader sequence found on a high percentage of nematode transcripts (Blumenthal and Steward 1997). In C. elegans, the trans-splice site tends to be very close to the translation initiation codon (Blumenthal and Steward 1997) and, in the 34C04 cDNA, the leader sequence was spliced $9 \mathrm{bp}$ from the initiating methionine codon. The spiced-leader (SL) sequence of 34C04, previously described from M. incognita (Ray et al. 1994) and designated SL1M (Koltai et al. 1997), differs from the nematode conserved canonical SL1 only by a single nucleotide at position 19 . Interestingly, the transcript of a pectate lyase gene cloned from $M$. javanica, which shares $96 \%$ sequence identity at the amino acid level with the $M$. incognita gene identified here, also contains the SL1M (Doyle and Lambert 2002). The absence of a SL sequence on 36 putative parasitism gene cDNAs, as well as the limited number of parasitism gene homologues in C. elegans, suggests a substantial divergence in evolution of nematodes for parasitism and the potential limitation of C. elegans as a model for parasitic nematodes.

Clone 30G11 encoded an acid phosphatase preceded by a signal peptide. Although acid phosphatase is the signature enzyme for lysosomes, which function in intracellular digestion, the expression of the clone only in the subventral gland cells may indicate a digestive role for the enzyme if it is secreted into host cells. Acid phosphatase was previously localized cytochemically in secretory granules in the subventral esophageal gland cells of $M$. incognita (Sundermann and Hussey 1988). The cellulose-binding protein encoded by clone $42 \mathrm{G} 06$ previously was cloned from $M$. incognita (Ding et al. 1998). Expression of a recombinant cellulose-binding domain in plant tissue modulates the elongation of different plant cells in vitro (Shpigel et al. 1995), indicating the possibility of the novel cellulose binding protein secreted by $M$. incognita having a role in the development of the feeding cells (giant-cells) in susceptible host roots (Ding et al. 1998).

Over $30 \%$ of the candidate parasitism genes were expressed in the subventral gland cells, which are the most active esophageal glands in the preparasitic and migratory parasitic second-stage juveniles. However, the morphology of the secretory granules and the subventral gland cells noticeably change once $M$. incognita establishes a feeding relationship with its host (Hussey and Mims 1990). The single dorsal gland cell becomes the predominate source of secretions during the rest of the parasitic cycle. In addition, nine of the candidate parasitism genes expressed in subventral gland cells have no functional homologues in other organisms. Although cell wall-degrading enzymes (i.e., cellulases and pectate lyases) represent important secretions released from the subventral esophageal gland cells of plant-parasitic nematodes (Davis et al. 2000), the high percentage of novel parasitism genes expressed in these glands in $M$. incognita indicates that the role or roles of secretions originating in the subventral gland cells may extend beyond simply being involved in nematode migration in host roots. The expression of calreticulin and chorismate mutase genes in the subventral gland cells of root-knot nematodes also supports this hypothesis (Jaubert et al. 2002; Lambert et al. 1999).

Efficient characterization of stylet secretions originating in the esophageal gland cells will accelerate our understanding of the molecular genetics of Meloidogyne spp.-plant interactions. Interspecific and intraspecific comparison of the structure of parasitism genes encoding stylet secretions that induce giantcell formation will provide the knowledge that should lead to establishing a genetic basis for host range specificity among Meloidogyne spp. or races. The procedure outlined herein uses a novel strategy for rapidly cloning parasitism genes encoding these secretory proteins. Functional assays will be required to confirm the role of the putative parasitism genes in the $M$. incognita-host interactions.

\section{MATERIAL AND METHODS}

\section{Microaspiration of gland cell cytoplasm.}

$M$. incognita was cultured on roots of greenhouse-grown tomato (Lycopersicon esculentum cv. Marion). Various parasitic 
stages of $M$. incognita were hand dissected from infected tomato roots, surface disinfested, and embedded in $0.7 \%$ agarose. The cytoplasm of the esophageal gland cells of 43 different viable nematodes covering the full range of parasitic stages were aspirated into glass micropipettes containing $10 \mu \mathrm{l}$ of mRNA extraction buffer to minimize nuclease degradation of the mRNA and transferred into separate microcentrifuge tubes for storage at $-80^{\circ} \mathrm{C}$ until used (Gao et al. 2001).

\section{Gland cell cDNA amplification by LD-PCR.}

Poly $(\mathrm{A})^{+}$RNA was purified from the cytoplasm aspirated from the esophageal gland cells using Dynabeads Oligo $(\mathrm{dT})_{25}$ magnetic beads (Dynal, Lake Success, NY, U.S.A.) and eluted with $5 \mu \mathrm{l}$ of diethyl pyrocarbonate (DEPC)-treated $\mathrm{d}_{2} \mathrm{H}_{2} \mathrm{O}$ as previously described (Gao et al. 2001). Gland cell first-strand cDNA synthesis was carried out in $0.5-\mathrm{ml}$ reaction tubes in a total $10-\mu \mathrm{l}$ volume of $4 \mu \mathrm{l}$ of mRNA sample, $0.5 \mu \mathrm{l}$ of $10 \mu \mathrm{M}$ 3'-RACE cDNA Synthesis Primer (Clontech Laboratories, Palo Alto, CA, U.S.A.), $0.5 \mu \mathrm{l}$ of $10 \mu \mathrm{M}$ SMART II oligonucleotide (Clontech), $2.0 \mu \mathrm{l}$ of $5 \times$ first strand buffer, $1.0 \mu \mathrm{l}$ of 20 $\mathrm{mM}$ DTT, $1.0 \mu \mathrm{l}$ of $10 \mathrm{mM} 50 \times \mathrm{dNTP}$, and $1.0 \mu \mathrm{l}$ of Superscript II (200 units/ $\mu \mathrm{l}$; GIBCO-BRL, Grand Island, NY, U.S.A.). The SMART oligonucleotide system was used to enrich for full-length cDNA for subsequent signal peptide analyses. The tubes were incubated at $42^{\circ} \mathrm{C}$ for $1.5 \mathrm{~h}$ and $90 \mu \mathrm{l}$ of TE buffer (10 mM Tris [pH 7.6], $1 \mathrm{mM}$ EDTA) was added. Diluted (10×) first-strand reaction solution $(10 \mu \mathrm{l}), 2 \mu \mathrm{l}$ of $10 \mathrm{mM}$ dNTP mix, $10 \mu \mathrm{l}$ of TaqPlus Long $10 \times$ low salt buffer, $1 \mu \mathrm{l}$ of TaqPlus Long polymerase (Stratagene, La Jolla, CA, U.S.A.), and $2 \mu \mathrm{l}$ of Nested Universal Primer (Clontech) were used in a total $100-\mu \mathrm{l}$ volume of LD-PCR reaction. LD-PCR was performed with hot start followed by 24 cycles at $94^{\circ} \mathrm{C}(20 \mathrm{~s})$, $65^{\circ} \mathrm{C}(30 \mathrm{~s})$, and $72^{\circ} \mathrm{C}(6 \mathrm{~min})$. Negative controls of DEPC water were performed at each reaction step above.

\section{Construction of gland-cell LD-PCR cDNA library.}

A gland-cell LD-PCR cDNA library was created from the LD-PCR amplification product derived from first-strand glandcell cDNA using the pGEM-T Easy (Promega, Madison, WI, U.S.A.) vector (Gao et al. 2001). The cDNA was purified with QIAquick PCR Purification Kit (Qiagen, Valencia, CA, U.S.A.) prior to ligation. Ligations were carried out at a mass ratio $3: 1$ (plasmid:cDNA) at $4^{\circ} \mathrm{C}$ overnight. Ligation products were precipitated with $10 \mathrm{mM}$ glycogen and $95 \%$ ethanol followed by a wash with $70 \%$ ethanol. The purified ligation products were heat-shock transformed into Escherichia coli XL10GOLD ultracompetent cells (Stratagene). The efficiency of the transformation was $10^{9}$ clones/ $\mu$ g of vector. EcoRI was used to check the insert size range in the pGEM-T Easy vector. White colonies (on blue-white selection) of the gland-cell LD-PCR cDNA library were hand picked at random $(6,144$ total) and transferred to 96-well MICROTEST III Tissue Culture plates (Becton Dickinson, Franklin Lakes, NJ, U.S.A.) containing $200 \mu \mathrm{l}$ of $10 \%$ glycerol Luria-Bertani medium with ampicillin and incubated overnight at $37^{\circ} \mathrm{C}$ prior to macroarraying onto sterile Hybond-XL nylon membranes (70 by 105 mm; Amersham Pharmacia Biotech, Piscataway, NJ, U.S.A.).

\section{cDNA sequencing and data analysis.}

The macroarrayed gland-cell LD-PCR cDNA library was hybridized with cDNA probes from a LD-PCR cDNA library generated from the intestinal cells of 10 parasitic $M$. incognita as described above to remove common expressed housekeeping and structural genes (Gao et al. 2001). Intestinal cDNAs were purified with QIAquick PCR Purification Kit (Qiagen) and $20 \mathrm{ng}$ of cDNAs were labeled with $\left[\alpha^{32} \mathrm{P}\right] \mathrm{dCTP}$ in one labeling reaction. The mixed probes were hybridized to a macro- array membrane of the gland-cell cDNA library, and clones not hybridizing to the intestinal cDNA (i.e., clones expressed specifically in the esophageal gland cells) were randomly selected for $5^{\prime}$-end single pass cDNA sequencing using the primer $5^{\prime}$ GGTAACAACGCAGAGTACGCG-3'. Sequencing reactions were prepared using an Applied Biosystems cycle sequencing kit. Sequences were collected on an ABI 3700 autosequencer (Applied Biosystems, Foster City, CA, U.S.A.). The average sequence read for the single pass sequencing was $528 \mathrm{bp}$.

Base calls and quality scores from the raw chromatograph files from the ABI 3700 Sequencer were generated with Phred (Ewing and Green 1998; Ewing et al. 1998). Sequencher (GeneCodes Corporation, Ann Arbor, MI, U.S.A.) was used to process (remove low-quality sequence from the ends of each read and vector sequence) the individual sequence files using the Phred base calls and quality scores. Contigs of the highquality sequences $(2,452)$ were assembled using Sequencher with a criteria of an $85 \%$ minimum match in at least a 50-bp overlap. The high quality sequences in fasta format were batchBLASTed using the BLAST client software, blastcl3, at the NCBI website. A BLASTX search was performed to determine sequence identity at the protein level and the results were compiled into a Microsoft Excel-based database, with the aid of MuSeqBox (Xing and Brendel 2000). Analysis for an N-terminal signal peptide sequence for secretion was conducted on all translated processed sequences using SignalP from the Center for Biological Analysis website. Subcellular localization sites of the deduced proteins were predicted by PSORT II computer analysis. The predicted proteins encoded by cDNAs expressed in the gland cells were analyzed again with NCBI's PSIBLASTP with novel sequences $(E$ value $<0.005)$ designated as "pioneers". The SMART database was used for domain analysis of the predicted proteins.

The 3'-RACE was used to obtain full-length cDNAs for putative parasitism genes with truncated $3^{\prime}$ ends. Mixed parasitic stages $(150 \mu \mathrm{l})$ of $M$. incognita were frozen in $1.5-\mathrm{ml}$ microcentrifuge tubes with liquid nitrogen and ground with a smooth-end metal bar. mRNA was purified with Oligo $(\mathrm{dT})_{25}$ magnetic beads and eluted with $20 \mu$ of DEPC-treated water. Reverse transcription and 3'-RACE were carried out with SMART RACE cDNA Amplification Kit (Clontech) according to the manufacturer's instructions. Universal Primer Mix A and gene-specific primers were used for PCR amplification. The amplified PCR products were cloned into pGEM-T Easy Vector (Promega) for sequencing.

\section{Developmental expression of candidate parasitism genes.}

The 185 cDNA clones with predicted signal peptides were screened by high-throughput in situ mRNA hybridization in $M$. incognita specimens. Gene-specific forward and reverse primers for each gene were used to synthesize digoxigenin (DIG)labeled antisense cDNA probes by asymmetric PCR amplification. The PCR reactions were performed in a $20-\mu$ reaction mixture with PCR DIG-labeling mix (Boehringer Mannheim, Mannheim, Germany) in the asymmetric PCR instead of dNTP in the normal PCR. In situ hybridization was performed as described by de Boer and associates (1998), but modified for high-throughput in situ screening (Gao et al. 2001). Preparasitic second-stage juveniles were collected by hatching eggs on sieves with $25-\mu \mathrm{m}$ openings suspended over deionized water in plastic bowls (Ding et al. 1998). Mixed parasitic stages of $M$. incognita were collected 13 to 15 days after inoculation of plants by root maceration and sieving (de Boer et al. 1999). Nematodes, fixed in $10 \%$ phosphate-buffered ( $\mathrm{pH} 7.0$ ) formalin, were cut randomly on glass slides with a razor blade and then partially digested with proteinase-K (Boehringer Mannheim) at $500 \mathrm{ng} / \mathrm{ml}$ at $37^{\circ} \mathrm{C}$ for $1 \mathrm{~h}$. After prehybridization, 
nematode sections in hybridization solution were aliquoted to wells of 96-well MultiScreen plate (Millipore, Bedford, MA, U.S.A.). Denatured PCR DIG-labeled DNA probes $(2 \mu \mathrm{l})$ were added to each well and solutions were changed by aspiration using the Millipore MultiScreen vacuum manifold (Gao et al. 2001). Substrate for alkaline phosphatase-conjugated anti-DIG was used to visualize hybridized cDNA probes within nematode specimens with a compound light microscope (de Boer et al. 1998).

\section{ACKNOWLEDGMENTS}

We thank S. Kamoun for help with high-throughput signal peptide analyses. Support for this research was provided by the National Research Initiative Competitive Grants Program of the Cooperative State Research, Education, and Extension Service of the United States Department of Agriculture under Agreement Nos. 99-35302-8080, the Iowa Soybean Promotion Board, the Iowa Agriculture and Home Economics Experiment station (Project No. 3381), by Hatch Act and State of Iowa, and by state and Hatch Funds allocated to the Georgia Agricultural Experiments.

\section{LITERATURE CITED}

Blumenthal, T., and Steward, K. 1997. RNA processing and gene structure. Pages 117-146 in: C. elegans II. D. L. Riddle, T. Blumenthal, B. J. Meyer, and J. R. Priess, eds. Cold Spring Harbor Laboratory Press, Cold Spring harbor, NY.

Dautova, M., Rosso, M-N., Abad, P., Gommers, F. J., Bakker, J., and Smant, G. 2001. Single pass cDNA sequencing - a powerful tool to analyze gene expression in preparasitic juveniles of the southern rootknot nematode Meloidogyne incognita. Nematology 3:129-139.

Davis, E. L., Allen, R., and Hussey, R. S. 1994. Developmental expression of esophageal gland antigens and their detection in stylet secretions of Meloidogyne incognita. Fundam. Appl. Nematol. 17:255-262.

Davis, E. L., Hussey, R. S., Baum, T. J., Bakker, J., Schots, A., Rosso, MN., and Abad, P. 2000. Nematode parasitism genes. Annu. Rev. Phytopathol. 38:365-396.

De Boer, J. M., McDermott, J. P., Davis, E. L., Hussey, R. S., Smant, G., and Baum T. J. 2002. Cloning of a putative pectate lyase gene expressed in the subventral esophageal glands of Heterodera glycines. J. Nematol. 33:9-11.

De Boer, J. M., Yan, Y., Smant, G., Davis, E. L., and Baum, T. J. 1998. In-situ hybridization to messenger RNA in Heterodera glycines. J. Nematol. 30:309-12.

De Boer, J. M., Yan, Y., Wang, X., Smant, G., Hussey, R. S., Davis, E. L., and Baum, T. J. 1999. Developmental expression of secretory $\beta$-1,4endoglucanases in the subventral esophageal glands of Heterodera glycines. Mol. Plant-Microbe Interact. 12:663-669.

Ding, X., Shields, J., Allen, R., and Hussey, R. S. 1998. A secretory cellulose-binding protein cDNA cloned from the root-knot nematode (Meloidogyne incognita). Mol. Plant-Microbe Interact. 11:952-959.

Doyle, E. A., and Lambert, K. N. 2002. Cloning and characterization of an esophageal-gland-specific pectate lyase from the root-knot nematode Meloidogyne javanica. Mol. Plant-Microbe Interact. 15:549-556.

Ewing, B., and Green, P. 1998. Base-calling of automated sequencer traces using phred. II. Error probabilities. Genome Res. 8:186-194.

Ewing, B., Hillier, L., Wendl, M. C., and Green, P. 1998. Base-calling of automated sequencer traces using phred. I. Accuracy assessment. Genome Res. 8:175-185.

Gao, B., Allen, R., Maier, T., Davis, E. L., Baum, T. J., and Hussey, R. S. 2001. Identification of putative parasitism genes expressed in the esophageal gland cells of the soybean cyst nematode, Heterodera glycines. Mol. Plant-Microbe Interact. 14:1247-1254.

Goverse, A., van der Voort, J. R., van der Voort, C. R., Kavelaars, A., Smant, G., Schots, A., Bakker, J., and Helder, J. 1999. Naturally induced secretions of the potato cyst nematode co-stimulate the proliferation of both tobacco leaf protoplasts and human peripheral blood mononuclear cells. Mol. Plant-Microbe Interact. 12:872-881.

Hussey, R. S. 1989. Disease-inducing secretions of plant-parasitic nematodes. Annu. Rev. Phytopathol. 27:123-141.
Hussey, R. S., and Grundler, F. M. 1998. Nematode parasitism of plants. Pages 213-243 in: Physiology and Biochemistry of Free-Living and Plant-Parasitic Nematodes. R. N. Perry and D. J. Wright, eds. CAB International Press, Wallingford, U.K.

Hussey, R. S., and Mims, C. W. 1990. Ultrastructure of esophageal glands and their secretory granules in the root-knot nematode Meloidogyne incognita. Protoplasma 156:9-18.

Hussey, R. S., and Mims, C. W. 1991. Ultrastructure of feeding tubes formed in giant-cells induced in plants by the root-knot nematode Meloidogyne incognita. Protoplasma 162:99-107.

Jaubert, S., Ledger, T. N., Laffaire, J. B., Piotte, C., Abad. P., and Rosso, M-N. 2002. Direct identification of stylet secreted proteins from rootknot nematode by a proteomic approach. Mol. Biochem. Parasitol. 121:205-211.

Koltai, H., Spiegel, Y., and Blaxter, M. L. 1997. Regulated use of an alternative spliced leader exon in the plant parasitic nematode Meloidogyne javanica. Mol. Biochem. Parasitol. 86:107-110.

Lambert, K. N., Allen, K. D., and Sussex, L. M. 1999. Cloning and characterization of an esophageal-gland-specific chorismate mutase from the phytoparasitic nematode Meloidogyne javanica. Mol. PlantMicrobe Interact. 12:328-336.

Lindsey, K., Casson, S., and Chilley, P. 2002. Peptides: new signalling molecules in plants. Trends Plant Sci. 7:78-83.

Lupas, A. 1996. Coiled coils: new structures and new functions. Trends Biochem. Sci. 21:375-382

Popeijus, H., Overmars, H., Jones, J., Blok, V., Goverse, Helder, J., Schots, A., Bakker, J., and Smant, G. 2000. Degradation of plant cell walls by a nematode. Nature 406:36-37.

Ray, C., Abbott, A. G., and Hussey, R. S. 1994. Trans-splicing of a Meloidogyne incognita mRNA encoding a putative esophageal gland protein. Mol. Biochem. Parasitol. 68:93-101.

Rosso, M.-N., Favery, B., Piotte, C., Arthaud, L., De Boer, J. M., Hussey, R. S., Bakker, J., Baum, T. J., and Abad. P. 1999. Isolation of a cDNA encoding a $\beta$-1,4-endoglucanase in the root-knot nematode Meloidogyne incognita and expression analysis during plant parasitism. Mol. Plant-Microbe Interact. 12:585-591.

Shpigel, E., Roiz, L., Goren, R., and Shoseyov, O. 1995. Bacterial cellulose-binding domain modulates in vitro elongation of different plant cells. Plant Physiol. 117:1185-1194.

Smant, G., Stokkermans, J. P. W. G., Yan, Y., de Boer, J. M., Baum, T. J., Wang, X., Hussey, R. S., Gommers, F. J., Henrissat, B., Davis, E. L., Helder, J., Shots, A., and Bakker, J. 1998. Endogenous cellulases in animals: isolation of $\beta-1,4$-endoglucanase genes from two species of plant-parasitic cyst nematodes. Proc. Natl. Acad. Sci. U.S.A. 95:49064911.

Sundermann, C. A., and Hussey, R. S. 1988. Ultrastructural cytochemistry of secretory granules of esophageal glands of Meloidogyne incognita. J. Nematol. 20:141-149.

Xing, L., and Brendel, V. 2000. MuSeqBox: a program for multi-query sequence BLAST output examination. Bioinformatics 17:744-745.

Wang, X., Allen, R., Ding, X., Goellner, M., Maier, T., de Boer, J. M., Baum, T. J., Hussey, R. S., and Davis, E. L. 2001. Signal peptideselection of cDNA cloned directly from the esophageal gland cells of the soybean cyst nematode, Heterodera glycines. Mol. Plant-Microbe Interact. 14:536-544.

Wang, X., Meyers, D., Yan, Y., Baum, T., Smant, G., Hussey, R., and Davis, E. 1999. In planta localization of a $\beta$-1,4-endoglucanase secreted by Heterodera glycines. Mol. Plant-Microbe Interact. 12:64-67.

Williamson, V. M., and Hussey, R. S. 1996. Nematode pathogenesis and resistance in plants. Plant Cell 8:1735-1745.

Yan, Y., Smant, G., Stokkermans, J., Qin, L., Helder, J., Baum, T., Schots, A., and Davis, E. 1998. Genomic organization of four $\beta$-1,4-endoglucanase genes in plant-parasitic cyst nematodes and its evolutionary implications. Gene 220:61-70.

\section{AUTHOR-RECOMMENDED INTERNET RESOURCES}

SMART (Simple modular architecture research tool) database: smart. embl-heidelberg.de.

NCBI BLAST server website: www.ncbi.nlm.nih.gov/blast/index.html.

The Center for Biological Analysis website: www.cbs.dtu.dk/services/ SignalP/index.html.

PSORT WWW server website: psort.nibb.ac.jp. 